\title{
Turkey's Competition with the EU in the US Market in the Context of TTIP
}

\author{
Seda Ekmen Özçelik
}

\begin{abstract}
This study analyzes the potential effects of the Transatlantic Trade and Investment Partnership (TTIP) on Turkey's trade patterns in the US market against the EU. Therefore, this study aims to determine the sectors in which Turkey competes relatively more strongly with the EU in the US market. Moreover, taking into account the product heterogeneity within the sectors, this study focuses on whether this competition relies on price differentials or not. To do so, we carry out a detailed analysis of exports of Turkey and the EU based on export product similarity and price similarity indices. The study covers the 2010-2014 period at country- and sector-levels, using disaggregated product data. Our results show that even Turkey's competition with the $E U$ in the US market is not so strong in general, there are still some sectors in which the degree of competition is quite considerable such as textiles and textile products; articles of stone, plaster, cement, ceramic and glass; arms and ammunition; vegetable products; animal or vegetable fats or oils. Moreover, except in the "arms and ammunition" sector, the TTIP has the potential to change trade patterns in favor of the EU, while Turkey is likely to lose competitiveness in these sectors.
\end{abstract}

Index Terms-TTIP, Turkey, EU, export Competition, US market.

\section{INTRODUCTION}

Negotiations have recently started between the United States (US) and the European Union (EU) within the context of Transatlantic Trade and Investment Partnership (TTIP). The US and the EU have decided to establish a trade and investment partnership in order to strengthen their own partnership and economic power against the emerging economies. On the 13th of February in 2013, talks between the US and the EU took place to launch the negotiations. The eleventh round of negotiations took place between 19 and 23 October 2015 in Miami. The twelfth round of negotiations is scheduled to take place on the 22nd of February, 2016 in Brussels.

The TTIP aims at eliminating existing tariff and non-tariff barriers in goods and services in order to make trade between the US and the EU easier, and to facilitate bilateral investment flows. Therefore, the major purpose of the TTIP is to deepen the economic integration between the US and the EU. Even if the final form of the agreement has not been decided yet, the possible effects of the TTIP on the EU, the US and the third

Manuscript received April 4, 2016; revised August 4, 2016.

Seda Ekmen Özçelik is with Yıldırım Beyazıt University, Turkey (e-mail: ekmen@ybusm.info). countries have become a heated subject of debate.

TTIP is an agreement in the making, which can be expected to have considerable influences on Turkey's trade with the US. From Turkey's viewpoint, the TTIP is more than a simple partnership between its two important trading partners. Turkey is a country that can be directly affected by the TTIP due to its Customs Union with the EU. That is to say, the TTIP will enable the US goods to get easier access to Turkey due to the Customs Union, but Turkish goods will continue to face trade barriers in the US market. This situation will make worse the trade balance of Turkey with the US, and also will reduce the competitiveness of Turkish exporters against its EU competitors in the US market. In fact, the TTIP has been criticized because of its potential to alter the trade patterns between the US and EU's closest trade partners - most notably that of Mexico, Canada, Japan and Turkey.

In this dynamic framework, Turkey has a special interest in taking measures against the potential negative impacts of the TTIP on Turkish economy. The question of Turkey's inclusion in the partnership seems to be open-ended in the predictable future. For Turkey, signing a parallel free trade agreement with the US can be an option. In any case, what seems important for Turkey is that challenges and opportunities associated with the possibility of maintaining a strong transatlantic relationship with the US should be clearly determined.

This study analyzes the potential effects of the TTIP on Turkey's trade patterns in the US market against the EU. To do so, I carry out a detailed and extensive analysis of Turkish exports to the US market, based mainly on "export similarity". In the light of the usages of export similarity in the literature, the main purpose of this study is to determine the patterns of specialization and degree of competition between Turkey and the EU in the US market. This study also analyzes "product heterogeneity" within sectors by focusing on price differences between Turkey and the EU.

In this way, this study aims to determine Turkey's export sectors that will be affected most by the tariff and non-tariff reductions between the US and the EU in the context of the TTIP. I also propose trade policies that would mitigate the unfavorable effects of the TTIP on Turkey's trade sectors.

The study covers the 2010-2014 period at country- and sector-levels. Analyses are based on disaggregated product-level data (HS at the 5-digit level). I measure "export similarity" between EU-28 countries and Turkey by calculating "export product similarity" and "price similarity" indices.

Since the TTIP is a quite new issue, there are limited numbers of academic studies on this subject-matter. And, only a few of them analyze in detail the potential impacts of the 
TTIP on the third countries, such as Turkey. For example, Akman (2014) summarizes Turkey's position in the EU-US transatlantic trade in a descriptive manner, drawing attention to the possible negative effects of the TTIP on Turkey's trade balance with the US, and also to the potential decreases in Turkey's competitiveness in the US market against the European products [1]. Kırışcı (2013) also deals descriptively with the negative impacts of the TTIP on Turkey [2]. To my knowledge, the only analytical study on the effects of the TTIP on Turkey has been carried out by Mavuş, Oduncu and Güneş (2013) [3]. They use a general-equilibrium framework of analysis, based on Global Trade Analysis Project (GTAP) database, and they mainly focus on the potential changes in Turkey's GDP in the cases of its inclusion in and exclusion from the TTIP. They find positive GDP changes if Turkey is included in the TTIP, and negative GDP changes if Turkey is excluded.

With respect to the previous works in the literature, this study is original in terms of empirically analyzing this important subject-matter by utilizing data at quite a disaggregated level with all export sectors. I examine the channels through which the export sectors will be affected, rather than focusing on how aggregate exports and the GDP will change as the result of the TTIP.

\section{DATA AND METHODOLOGY}

My analysis is based on US import data between 2010 and 2014, classified according to the HS-2007 classification at the six-digit level. I analyze the whole set of products and each one-digit HS sector separately. Data used in this study come from the United Nations Trade Statistics (UNCOMTRADE). The analysis of Turkey's exports with respect to the EU-28 exports in the US market is based on "product similarity" and "price similarity" indices.

\section{A. Product Similarity Index (PSI)}

An earlier version of the PSI was developed by Grubel and Llyod (1971) in order to analyze intra-industry trade between two countries [4]. Then, Antimiani and Henke (2007) modified this index in order to analyze the export similarity between two countries [5]. The PSI has also been used by Erlat and Ekmen (2009) in order to analyze the similarity of Turkish exports against non-EU-15 countries in the EU market [6]. The PSI is calculated as:

$$
P S I_{i}=1-\frac{\sum_{j}\left|X_{j(a, c)}^{i}-X_{j(b, c)}^{i}\right|}{\sum_{j}\left(X_{j(a, c)}^{i}+X_{j(b, c)}^{i}\right)}
$$

where PSI $i$ is the 'product similarity index' for countries $a$ (Turkey) and $b$ (EU-28) in the common market $c$ (US). $\mathrm{X}(a, c) i$ stands for the values of product $j$ exported from country $a$ to market $c$, and similarly $\mathrm{Xj}(b, c) i$ refers to the values of product $j$ exported from country $b$ to market $c$. Here, $i$ may also stand for a country as a whole or it may represent 6-digit HS production. The value of the index changes between 0 and 100, where 0 implies perfect dissimilarity while 100 implies perfect similarity between the exports of the two countries.

\section{B. Price Similarity Index (PRSI):}

PRSI has been developed by Erlat and Ekmen (2009) as a modified and expanded version of the "Quality Similarity Index" by Antimiani and Henke (2007).

PRSI is expressed as:

$$
\operatorname{PRSI}_{i q}=\left(\frac{\sum_{j=1}^{n_{i q}}\left(X_{j(a, c)}+X_{j(b, c)}\right)-\sum_{j=1}^{n_{i q}}\left|X_{j(a, c)}-X_{j(b, c)}\right|}{\sum_{j=1}^{n_{i}}\left(X_{j(a, c)}+X_{j(b, c)}\right)}\right)
$$

where $i$ indicates a one-digit sector, $n_{i}$ all 6 -digit products in a one-digit sector " $\mathrm{j}$ " indicates 6-digit products, and $n_{i q}$ the 6 -digit products in a one-digit sector that fall into a price category indicated by $q$ as given by the following expressions:

$$
\begin{gathered}
1-\alpha \leq \frac{U V_{X_{j},(a, c)}^{j}}{U V_{X_{j},(b, c)}^{j}} \leq 1+\alpha \\
\frac{U V_{X_{j},(a, c)}^{j}}{U V_{X_{j},(b, c)}^{j}}>1+\alpha \\
\frac{U V_{X_{j},(a, c)}^{j}}{U V_{X_{j},(b, c)}^{j}}<1-\alpha
\end{gathered}
$$

The PRSI measures the relative price by the unit values (UV) of exports, letting $j$ indicate 6 -digit products in the $i^{\text {th }}$ one-digit product, the UV for $X_{j(a, c)}$ by $U V_{X_{j},(a, c)}^{j}$ and the UV for $X_{j(b, c)}$ by $U V_{X_{j},(b, c)}^{j}$. The coefficient $\alpha$ is normally positioned between 0.15 and 0.25 . In the case of this study, $\alpha$ is selected as 0.15 .

The conditions that yield these categories are categorized as "medium price-similarity (PRSI-M)" (a), "higher-price-similarity (PRSI-H)" (b) and "lower-price similarity (PRSI-L)" (c), respectively.

By computing and evaluating the PSI and PRSI; I will determine the products for which Turkey's competition with the EU in the US market will be affected most within the context of the TTIP.

\section{RESULTS}

In this section, empirical results for the PSI and PRSI are presented at the country level (Overall) and for each HS sectors (1-20). The results are also presented for each year and for the average of the full-period (Average).

Table I below presents the "overall" results for the PSI between Turkey and the EU.

TABLE I: PSI BETWEEN TURKEY AND THE EU, 2010-2014

\begin{tabular}{|c|c|c|c|c|c|c|}
\hline & 2010 & 2011 & 2012 & 2013 & 2014 & Average \\
\hline Overall & 2.3 & 2.31 & 2.65 & 2.65 & 2.82 & $\mathbf{2 . 5 5}$ \\
\hline
\end{tabular}

According to Table-1, the PSI between Turkey and the EU is 2.55 on the average. According to Erlat and Ekmen (2009), the PSI coefficients for Turkey's strongest competitors in the EU market are around 30. Compared to this value, it can be argued that competition between Turkey and EU in the US market is not very strong. Therefore, it can be expected that, 
at the country level, Turkey's export competition with the EU will not be damaged significantly within the context of the TTIP.

Table II below presents the results at sector level for the PSI between Turkey and the EU.

TABLE II: PSI BETWEEN TURKEY AND THE EU FOR EACH HS-SECTOR, 2010-2014

\begin{tabular}{|c|c|c|c|c|c|c|}
\hline Sectors & 2010 & 2011 & 2012 & 2013 & 2014 & Average \\
\hline Overall & 2.30 & 2.31 & 2.65 & 2.65 & 2.82 & 2.55 \\
\hline Live animals; animal products & 1.96 & 1.13 & 1.74 & 2.42 & 2.96 & 2.04 \\
\hline Vegetable products & 6.75 & 6.75 & 7.68 & 10.40 & 9.65 & 8.25 \\
\hline Animal or vegetable fats or oils & 4.86 & 1.29 & 3.12 & 18.82 & 2.74 & 6.17 \\
\hline Prepared foodstuffs; beverages and tobacco & 3.06 & 3.40 & 3.65 & 3.61 & 3.98 & 3.54 \\
\hline Mineral products & 1.92 & 1.24 & 0.87 & 2.12 & 1.02 & 1.43 \\
\hline Products of the chemical or allied industries & 0.23 & 0.26 & 0.33 & 0.33 & 0.26 & 0.28 \\
\hline Plastics and articles thereof; rubber and articles thereof & 3.30 & 3.93 & 3.68 & 3.18 & 3.43 & 3.50 \\
\hline Raw hides and skins, leather, furskins, and articles thereof; & 4.35 & 4.22 & 4.16 & 4.52 & 4.50 & 4.35 \\
\hline Wood and articles of wood; & 0.08 & 0.18 & 0.28 & 0.26 & 0.53 & 0.27 \\
\hline Pulp of wood and paper and paperboard & 0.56 & 0.65 & 0.75 & 1.60 & 0.78 & 0.87 \\
\hline Textiles and textile products & 21.79 & 21.50 & 22.88 & 22.63 & 21.83 & 22.12 \\
\hline $\begin{array}{l}\text { Footwear, headgear, umbrellas, walking-sticks, seat-sticks, } \\
\text { article flowers; articles of human hair }\end{array}$ & 0.35 & 0.63 & 0.61 & 0.51 & 0.51 & 0.52 \\
\hline $\begin{array}{l}\text { Articles of stone, plaster, cement, asbestos, mica or similar } \\
\text { materials; ceramic products; glass and glass ware }\end{array}$ & 15.03 & 15.60 & 17.82 & 20.66 & 21.53 & 18.13 \\
\hline $\begin{array}{l}\text { Natural or cultured pearls, precious or semi-precious } \\
\text { stones, precious metals; imitation jewellery; coin }\end{array}$ & 4.39 & 3.03 & 3.67 & 3.13 & 3.42 & 3.53 \\
\hline Base metals and articles of base metal & 4.73 & 4.50 & 5.09 & 4.82 & 9.50 & 5.73 \\
\hline $\begin{array}{l}\text { Machinery and mechanical appliances; electrical } \\
\text { equipment; sound recorders and reproducers, television } \\
\text { image and sound recorders }\end{array}$ & 1.54 & 1.50 & 1.85 & 2.03 & 1.98 & 1.78 \\
\hline $\begin{array}{l}\text { Vehicles, aircraft, vessels, and associated transport } \\
\text { equipment }\end{array}$ & 2.92 & 3.39 & 3.68 & 2.08 & 2.12 & 2.84 \\
\hline $\begin{array}{l}\text { Optical, photographic, cinematographic, measuring, } \\
\text { checking, precision, medical or surgical instruments and } \\
\text { apparatus; clocks and watches; musical instruments; }\end{array}$ & 0.25 & 0.10 & 0.11 & 0.17 & 0.20 & 0.17 \\
\hline Arms and ammunition; parts and accessories thereof & 5.71 & 9.59 & 12.29 & 15.93 & 12.99 & 11.30 \\
\hline Miscellaneous manufactured articles & 1.69 & 1.56 & 1.98 & 2.15 & 2.77 & 2.03 \\
\hline
\end{tabular}

According to Table II, Turkey's competition with the EU is the strongest for textiles and textile products. The second strongest competition is observed in the sector "articles of stone, plaster, cement, ceramic and glass". Arms and ammunition, vegetable products, animal or vegetable fats or oils are the other sectors that Turkey competes strongly with the EU. In the other sectors, Turkey doesn't seem to be competing with the EU at all.

Table II also shows that degree of competition between Turkey and the EU in textile products is nearly constant throughout the period. On the other hand, Turkey's competition with the EU in "articles of stone, plaster, cement; ceramic products; glass" has increased over time. Similarly, the degree of competition in "arms and ammunition", "vegetable products" and "animal or vegetable fats or oils" has increased from 2010 to 2013.

In the next section, for these competing sectors, I will analyze PSI and PRSI together in order to determine the product groups for which Turkey's competition with the EU in the US market relies on price similarity.

Given these results so far, it can be argued that, in especially the strong-competition sectors, the relative prices of Turkey's exports will rise, because the TTIP will enable the EU to export to the US without tariffs, while Turkey will have to continue to export under the existing tariff conditions. Assuming that the US consumers don't have a special demand for Turkey's exports, and that their demand is mainly determined by the price factor; it can be argued that Turkey will encounter a disadvantageous position in terms of price competition in the US market. As such, competitiveness of the
EU against Turkey can be expected to increase significantly in these sectors.

Table III presents the results of the PSI and PRSI together for the product groups in which Turkey and the EU compete strongly.

TABLE III: PRSI BETWEEN TURKEY AND THE EU FOR THE GIVEN HS-SECTORS, 2010-2014 AVERAGE

\begin{tabular}{|l|c|c|c|c|}
\hline \multicolumn{1}{|c|}{ Sectors } & PSI & PRSI-L & PRSI-M & PRSI-H \\
\hline Textiles and textile products & 22.12 & 0.87 & $\mathbf{1 9 . 4 8}$ & 1.78 \\
\hline $\begin{array}{l}\text { Articles of stone, plaster, cement, asbestos, mica or similar } \\
\text { materials; ceramic products; glass and glass ware }\end{array}$ & 18.13 & 0.03 & $\mathbf{1 3 . 0 2}$ & 4.85 \\
\hline Arms and ammunition; parts and accessories thereof & 11.30 & 0.00 & 4.40 & $\mathbf{6 . 9 0}$ \\
\hline Vegetable products & 8.25 & 2.44 & $\mathbf{3 . 1 1}$ & 2.67 \\
\hline Animal or vegetable fats or oils & 6.17 & 0.12 & $\mathbf{4 . 4 2}$ & 1.62 \\
\hline
\end{tabular}

According to Table-3, most of the sectors fall into the category of PRSI-M, i.e., "medium" price similarity (textiles and textile products; articles of stone, plaster, cement, ceramic products; glass and glassware; vegetable products; and animal or vegetable fats or oils). In other words, except "arms and ammunition" (which falls into the category of "high" price similarity), the competition between Turkey and the EU is concentrated in the products with similar prices. Therefore, following the TTIP, those sectors will lose competitiveness against the EU products, since they will become disadvantageous in terms of prices.

On the other hand, in the "arms and ammunition" sector, competition between Turkey and the EU is concentrated in the products for which Turkish exports have relatively higher prices. Therefore, it can be claimed that there may be some factors other than price, which determine the degree of competition in this sector between Turkey and the EU in the US market. It can be expected that the general price disadvantage Turkey will face in the context of the TTIP will not be valid in the "arms and ammunition" sector. That is to say, this sector is not likely to be affected by the tariff reductions on EU products, because Turkey's price is already higher in this sector.

\section{CONCLUSION}

In this study, Turkey's export similarity with the EU in the US market has been analyzed within the context of the TTIP. The main conclusion is that Turkey's competition with the EU in the US market is not so strong in general. However, there are still some sectors in which the degree of competition is quite considerable. Turkey and the EU strongly competes in certain sectors (textiles and textile products; articles of stone, plaster, cement, ceramic and glass; arms and ammunition; vegetable products; animal or vegetable fats or oils).

Except in the "arms and ammunition" sector, the strong competition in the other sectors is likely to evolve into a disadvantageous price position on the part of Turkey. In other words, the TTIP has the potential to change trade patterns in favor of the EU, while Turkey is likely to lose competitiveness in these sectors. One policy conclusion for Turkey is that it should focus upon these export sectors individually, with the objective of reducing costs of production (and thus prices) through, for example, improving the technological infrastructure of these sectors. Special 
export incentives and promotions can also be provided to these sectors so that they can maintain their competitive position vis-à-vis the EU countries in the US market.

On the other hand, Turkey's prices are already higher in the case of the "arms and ammunition" sector, implying that competition with the EU in this sector arises mainly from non-price factors. Such non-price factors should be examined and determined carefully so that relevant policies can be designed in order to maintain and improve the competitiveness of this sector as well.

As a broader policy conclusion, Turkey can negotiate a free-trade agreement with the US, focusing especially on these strong-competition sectors. Provided that the US reduces and/or eliminates its import tariffs on Turkey's exports especially in these sectors, the potential negative effects of the TTIP on Turkey's exports will be minimized significantly.

\section{REFERENCES}

[1] D. M. Akman, "AB-ABD transatlantik ticaret ve yatirim ortakliği: türkiye açisindan bir değerlendirme," Ankara Avrupa Çalı̧̧maları Dergisi, vol. 13, no. 1, pp. 1-31, 2014.

[2] K. Kırışc1, "Turkey and the transatlantic trade and investment partnership - boosting the model partnership with the United States," The Center on the United States and Europe at Brookings Turkey Project, 2013.
[3] M. Mavuş, A. Oduncu, and D. Güneș, "The possible effects of transatlantic trade and investment partnership (TTIP) on turkish economy," MPRA Paper, No. 51900, 2013.

[4] H. G. Grubel and P. J. Lloyd, "The empirical measurement of intra-industry trade," Economic Record, vol. 47, no. 120, pp. 494-517, 1971.

[5] A. Antimiani and R. Henke, "Old and new partners: Similarity and competition in the EU Foreign trade," Food Economics-Acta Agriculturae Scandinavica Section C, vol. 4, no. 3, pp. 129-138, 2007.

[6] G. Erlat and S. Ekmen, "Export similarity and competitiveness: The case of Turkey in the EU Market," in Proc. Anadolu International Conference in Economics, 2009.

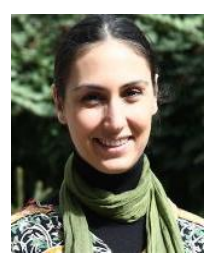

Seda Ekmen Özçelik was born in Ankara, Turkey in 1979.

She completed her undergraduate studies in Economics at Hacettepe University. After that, she was admitted as a research assistant by the Department of Economics at the Middle East Technical University. Between 2001 and 2012, she worked as a research assistant there; and at the same time she completed her Master's and $\mathrm{PhD}$ studies as a graduate student. She obtained her $\mathrm{PhD}$ degree in Economics in 2012 after successfully defending her PhD thesis. In her thesis, she basically focused upon Turkey's export competitiveness in the European Union market.

Seda Ekmen Özçelik has been working at the Yıldırım Beyazıt University as an assistant professor doctor since 2012. 